\title{
Microbial quality of industrial and retail market grated parmesan cheese in the State of São Paulo, Brazil
}

\author{
Comparação da qualidade microbiológica de queijos tipo parmesão ralados \\ industrialmente e no comércio varejista no Estado de São Paulo, Brasil
}

\author{
Carlos Eduardo Gamero Aguilar ${ }^{I^{*}}$ Oswaldo Durival Rossi Junior ${ }^{\mathrm{I}}$ \\ Ana Maria Centola Vidal ${ }^{I I}$ Laryssa Freitas Ribeiro ${ }^{\mathrm{I}}$ \\ Gabriel Augusto Marques Rossi ${ }^{\mathrm{I}}$
}

\section{ABSTRACT}

With the objective to evaluate the hygienic and sanitary conditions of grated parmesan cheese acquired from the retail business, total 120 cheese samples were acquired: 60 of which were obtained from four different brands of cheese that were grated in factories, and the other 60 samples were obtained from another four brands of cheese that are normally acquired by retailers (supermarkets) in blocks and grated at the moment of sale. The population of heterotrophic mesophilic microorganisms ranged from $1.2 \times 10^{3}$ to $1.1 \times 10^{7}$ colony-forming units $(\mathrm{CFU}) \cdot \mathrm{g}^{-1}$. All samples analyzed contained Staphylococcus spp. with populations varying from $1.2 \times 10^{3}$ to $8.7 \times 10^{6} \mathrm{CFU} \cdot \mathrm{g}^{-1}$, from which $60.0 \%$ were classified as coagulase-positive Staphylococcus and $52.5 \%$ of the samples possessed populations above the permissible limit set by legislation. Staphylococcus aureus was detected in $57.5 \%$ of the samples. Population of molds and yeasts varied from $<10$ to $1.8 \times 10^{6} \mathrm{CFU} \cdot \mathrm{g}^{-1}$. Salmonella spp. was not isolated in this research. A difference was observed between the parmesan cheese grated in factories and that grated in supermarkets, where the former presented better microbiological quality than the latter. Thus, procedures must be proposed to minimize the presence of pathogenic agents reported in grated parmesan cheeses evaluated in the present study because of the public health risk associated with food bacterial contamination.

Key Words: dairy, food microbiology, public health, Staphylococcus aureus.

RESUMO

Com o objetivo de avaliar as condições higiênicas e sanitárias de queijos tipo parmesão ralados, vendidos no comércio varejista, foram realizadas análises microbiológicas em 120 amostras, sendo 60 destas de quatro marcas comerciais, as quais foram raladas industrialmente e outras 60 de quatro marcas, cujos queijos foram adquiridos pelos comércios varejistas em grandes peças e ralados no ato da venda. As populações de microrganismos heterotróficos mesófilos variaram de $1,2 \times 10^{3}$ a $1,1 \times 10^{7} \mathrm{UFC} . \mathrm{g}^{-1}$. Todas as amostras analisadas apresentaram Staphylococcus spp., com populações que variaram de $1,2 \times 10^{3}$ a $8,7 \times 10^{6} U F C . g^{-1}$, sendo que 60,0\% dessas apresentaram Staphylococcus coagulase positivo e 52,5\% delas com populações acima do limite estabelecido pela legislação. A presença de Staphylococcus aureus foi identificada em 57,5\% das amostras. As populações de bolores e leveduras apresentaram variação de $<10$ a $1,8 \times 10^{6} \mathrm{UFC} . \mathrm{g}^{-1}$. Salmonella spp. não foi isolada no presente trabalho. Houve diferença entre os queijos ralados industrialmente e os queijos ralados nos supermercados, sendo que o primeiro grupo apresentou resultados de qualidade microbiológicas melhores do que o segundo grupo. Assim, medidas visando minimizar as populações de agentes contaminantes e deteriorantes encontradas nos queijos parmesão analisados no presente trabalho devem ser realizadas, visto que estas podem representar um risco à saúde pública.

Palavras-chave: laticinio, microbiologia de alimentos, saúde pública, Staphylococcus aureus.

\section{INTRODUCTION}

Cheese is a nutritive food, which can facilitate the multiplication of pathogenic microorganisms that cause foodborne diseases (MARINHEIRO et al., 2015). Food contamination can occur because of several factors, such as poor microbiological quality

IDepartamento de Medicina Veterinária Preventiva e Reprodução Animal, Faculdade de Ciências Agrárias e Veterinárias (FCAV), Universidade Estadual Paulista (UNESP), 14884-900, Jaboticabal, SP, Brasil. E-mail: kadugamero@hotmail.com. "Corresponding author.

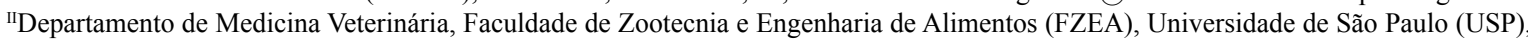
Pirassununga, SP, Brasil. 
of raw material, inadequately sanitized facilities and equipment, and improper manipulation and storage of products (MELLO \& ARMACHUK, 2013).

Among several types of cheese commonly sold in Brazil, parmesan cheese is one of the most consumed and is usually grated at the time of sale. Parmesan cheese is a hard, semi-fat, cooked, low-moisture cheese; it has a tough and granular texture with a thick, smooth, and straw-yellow crust (JASTER et al., 2014).

However, this cheese can pose a risk to public health due to several processing steps that are required before the final product is obtained. Consequently, production under improper conditions can have serious consequences on the population, becoming a public health threat (GAULIN et al., 2003).

Therefore, assessing the presence of certain microorganisms, such as coagulase-positive Staphylococci, Salmonella spp., mold, yeast, and enterobacteria, in parmesan cheese is of utmost importance because of the danger it poses to human health when consumed (SEIXAS, 2009).

Another important issue is the contamination of these products at the point-ofsale, mainly due to poorly sanitized equipment and utensils, which can contaminate food, making it unsafe for consumption. Lack of proper sanitization of equipment and utensils is responsible for up to $16 \%$ of foodborne disease outbreaks (ABREU et al., 2010a); thereby, highlighting that some markets and retails markets frequently have poor sanitization programs (SILVA, 2011; SOTO et al., 2009).

To assure the identity and safety of commercially sold grated cheeses, the Brazilian Ministry of Agriculture, Livestock and Food Supply created ordinance n. 357 on September 4, 1997 (BRASIL, 1997), which established the Technical Regulation of Identity and Quality of Grated Cheese. This ordinance sets a maximum limit of $10^{3}$ colonyforming units $(\mathrm{CFU}) \cdot \mathrm{g}^{-1}$ of coagulase-positive Staphylococcus and the absence of Salmonella spp. in $25 \mathrm{~g}$ of sample and a maximum mold and yeast count of $5 \times 10^{3} \mathrm{CFU} \cdot \mathrm{g}^{-1}$. However, this ordinance only applies to industrially produced grated cheese; cheese grated at retail markets falls under RDC n. 12 (BRASIL, 2001) regulation act, which states that for low-humidity cheeses, a maximum limit of $10^{3} \mathrm{CFU} \cdot \mathrm{g}^{-1}$ for coagulase-positive Staphylococcus is allowed with the absence of Salmonella spp. in $25 \mathrm{~g}$ of sample.

Because of the lack of information regarding the microbial integrity of grated parmesan cheese in the industry and at the point-of-sale in retail markets, this study focused on assessing and comparing the microbiological quality of currently available commercialized parmesan cheeses in the municipality of Ribeirão Preto, state of São Paulo.

\section{MATERIALS AND METHODS}

A set of 60 samples of parmesan cheese grated in industries under federal inspection were evaluated. The samples were collected from four different commercial brand (brands A, B, C, and D); 15 samples of each brand from the same batch. Another 60 samples of parmesan cheese of four different brands (E, F, G. and H) grated in retail markets were also collected with 15 samples per brand from the same batch. All 120 samples were obtained during 2013 in the municipality of Ribeirão Preto, state of São Paulo, Brazil. Markets purchased the parmesan cheese in large pieces that were kept refrigerated and were grated in the presence of the consumer during sale. The industry samples of grated parmesan cheese were maintained at room temperature (as sold) until laboratory analyses were performed; whereas, retail market samples were transported refrigerated to the laboratory in boxes containing recyclable ice (as sold).

A $25 \mathrm{~g}$ amount of each sample of grated cheese from its original packing was placed in sterile flasks containing $225 \mathrm{~mL}$ of $0.1 \%$ buffered peptone water and serially diluted till $10^{-4}$. The methodology described by the American Public Health Association (APHA, 2001) was adopted to assess the most probable number (MPN) of total coliforms $\cdot \mathrm{g}^{-1}$, MPN of thermotolerant coliforms and Escherichia coli per gram, standard count of aerobic or facultative heterotrophic mesophilic microorganisms, presence of Salmonella spp., and count of Staphylococcus spp., positive-coagulase Staphylococcus, and Staphylococcus aureus. Mesophilic microorganisms were counted using standard plate count agar (SPC; Oxoid), and plates were incubated at $35^{\circ} \mathrm{C}$ for $48 \mathrm{~h}$.

To analyze the presence of Salmonella spp., initial samples were pre-enriched and incubated at $37^{\circ} \mathrm{C}$ for $24 \mathrm{~h}$. Selenite cystine broth (Difco, Detroit, USA) and Rappaport-Vassiliadis broth (Difco, Detroit, USA) were used for selective enrichment. Subsequently, $0.1 \mathrm{~mL}$ of a $0.4 \%$ novobiocin solution (INLAB, São Paulo, Brazil) was added to the two broths. Selective plating was performed on brilliant green and MacConkey agars (Difco, Detroit, USA).

Counting of Staphylococcus spp. was performed using Petri dishes containing BairdParker agar (BPA; Difco Laboratories) supplemented 
with egg yolk-potassium tellurite, and the plates were incubated at $35^{\circ} \mathrm{C}$ for $48 \mathrm{~h}$. A coagulase test was performed using the isolates from brain-heart infusion broth and rabbit plasma to assess the presence of coagulase-positive strains. $\boldsymbol{S}$. aureus biochemical characterization was performed according to MacFaddin (1976).

The Kruskal-Wallis $(\mathrm{P}<0.05)$ statistical test was used to compare the mean count of mesophilic bacteria, Staphylococcus spp., positive coagulase Staphylococcus, $S$. aureus, mold, and yeast (THEODORSSON-NORHEIM, 1986). Whenever significant differences were observed, the Dunn's post hoc test for multiple comparisons was performed to detect the differences reported. All statistical analyses were performed using SAS statistical software 9.1.3 release (SAS Corporation, Cary, NC).

\section{RESULTS AND DISCUSSION}

Total coliforms, thermotolerant coliforms, and $\boldsymbol{E}$. coli were detected in the industrially grated (IG) cheese at $10.0 \%$ (six), $1.6 \%$ (one), and $1.6 \%$ (one) of samples, respectively. The maximum populations observed in each bacterial group were $210 \mathrm{MPN} \cdot \mathrm{g}^{-1}, 70 \mathrm{MPN} \cdot \mathrm{g}^{-1}$, and $70 \mathrm{MPN} \cdot \mathrm{g}^{-1}$, respectively. Analysis of the parmesan cheese grated at the time of sale (GTS) revealed $35.0 \%(21), 16.6 \%$ (10), and $16.6 \%$ (10) contaminated samples, with a maximum population of $500 \mathrm{MPN} \cdot \mathrm{g}^{-1}, 70 \mathrm{MPN} \cdot \mathrm{g}^{-1}$, and $23 \mathrm{MPN} \cdot \mathrm{g}^{-1}$, respectively.

Although samples contained detectable levels of microorganisms, the amounts were below the limits established by the RDC n. 12 legislation (BRAZIL, 2001), thereby not hindering the sales of these products. One possible reason for the low count of $\boldsymbol{E}$. coli is that the bacteria require more water activity than is present in parmesan cheese (ABREU et al., 2010a).

Salmonella spp. was not isolated from any of the samples. The arithmetic means and standard deviation of the mesophilic, Staphylococcus spp., positive-coagulase Staphylococcus, $\boldsymbol{S}$. aureus, mold, and yeast populations are presented in tables 1 and 2 .

A significant statistical difference (Dunn's test, $\mathrm{P}<0.05$ ) was observed between the heterotrophic mesophilic microorganism population of the IG group and of the GTS group. The latter group presented a higher population of microorganisms. Detecting heterotrophic mesophilic microorganisms in food can provide information regarding the hygienic and sanitary characteristics of the product. High amounts of microorganisms suggested contamination of the raw product, inappropriate processing conditions, or inadequate storage. Thus, the presence of these microorganisms poses a risk to the consumer's health and contributes to the deterioration of the product (MONTANHINI et al., 2013). High amounts of these microorganisms also indicated a greater possibility of pathogens being present in the food as most pathogens are mesophilic bacteria (MADIC et al., 2011).

Despite the fact that Brazilian law has no set limit for the amount of heterotrophic mesophilic microorganisms allowed in grated parmesan cheese, some groups have suggested that cheese with microbial populations larger than $10^{6} \mathrm{CFU} \cdot \mathrm{g}^{-1}$ should not be consumed (ICMSF, 1981) due to the risk of foodborne diseases (JAY, 2005). Mesophilic bacterial counts higher than $10^{6} \mathrm{CFU} \cdot \mathrm{g}^{-1}$ were observed in grated cheese samples from retail markets as shown in table 1.

Although errors while processing food products frequently occur, most food contamination is usually due to incorrect manipulation of products in markets (DAMER, 2015). This is in accordance with the research findings, in which $88.3 \%$ of GTS samples had bacterial counts higher than $10^{6} \mathrm{CFU} \cdot \mathrm{g}^{-1}$; whereas, IG samples had lower counts, confirming the higher risk associated with consuming GTS cheese.

Considering that all industrial processes were performed under the same hygienic and sanitary rigor as all analyzed brands were from industries under federal sanitary inspection, the differences in the microorganism population found between the IG and GTS groups is probably due to inadequate manipulation of the blocks of parmesan cheese or even poor cleaning of the grating machines at markets.

The Staphylococcus population ranged from $1.2 \times 10^{3}$ to $1.8 \times 10^{4} \mathrm{CFU} \cdot \mathrm{g}^{-1}$ in the IG samples and from $1.2 \times 10^{5}$ to $8.7 \times 10^{6} \mathrm{CFU} \cdot \mathrm{g}^{-1}$ in the GTS samples. These results were statistically different when analyzed using the Dunn's test $(\mathrm{P}<0.05)$; thus, confirming that the IG samples had a lower microbial population than that in the GTS samples. The assessment of Staphylococcus in food is critical as over 20 its species can cause several diseases in humans (KANDARIYA et al., 2014). Moreover, Staphylococcus is one of the most common causes of foodborne illnesses (SCALLAN et al., 2011) and is the main source of contamination in inadequately handled food (ARGUDÍN et al., 2012).

In the USA, sources have reported that $25.3 \%-48.3 \%$ of staphylococcal food poisoning 
Table 1 - Arithmetic means and standard deviation of heterotrophic mesophilic bacteria, mold, and yeast found in each brand of industrially grated (IG) and grated at the time of sale (GTS) parmesan cheese collected from markets at Ribeirão Preto, São Paulo.

\begin{tabular}{lcc}
\hline & & \\
Brand & Mesophilic & Molds and Yeast \\
\hline A (IG) & $9.8 \times 10^{4 \mathrm{bc}} \pm 1.3 \times 10^{4}$ & $3.3 \times 10^{1 \mathrm{c}} \pm 6.2 \times 10^{1}$ \\
B (IG) & $1.8 \times 10^{4 \mathrm{~cd}} \pm 3.5 \times 10^{3}$ & $1.3 \times 10^{3 \mathrm{bc}} \pm 1.0 \times 10^{3}$ \\
C (GG) & $1.4 \times 10^{4 \mathrm{~d}} \pm 6.9 \times 10^{3}$ & $5.4 \times 10^{2 \mathrm{bc}} \pm 6.3 \times 10^{2}$ \\
D (IG) & $3.6 \times 10^{4 \mathrm{~d}} \pm 1.7 \times 10^{4}$ & $6.6 \times 10^{2 \mathrm{bc}} \pm 6.2 \times 10^{2}$ \\
E (GTS) & $5.3 \times 10^{6 \mathrm{ab}} \pm 3.7 \times 10^{6}$ & $4.6 \times 10^{5 \mathrm{a}} \pm 6.2 \times 10^{5}$ \\
F (GTS) & $6.8 \times 10^{6 \mathrm{a}} \pm 3.9 \times 10^{6}$ & $8.2 \times 10^{4 \mathrm{ab}} \pm 2.1 \times 10^{5}$ \\
G (GTS) & $5.1 \times 10^{6 \mathrm{ab}} \pm 3.5 \times 10^{6}$ & $2.3 \times 10^{5 \mathrm{a}} \pm 2.5 \times 10^{5}$ \\
H (GTS) & $5.0 \times 10^{6 \mathrm{ab}} \pm 3.1 \times 10^{6}$ & $3.1 \times 10^{5 \mathrm{a}} \pm 3.7 \times 10^{5}$ \\
\hline
\end{tabular}

Means followed by the same letters in the column do not differ according to the Dunn's test (5\% significance level).

outbreaks were due to contamination by food handlers (BEAN et al., 1997); thus, confirming the impact professionals have in spreading Staphylococcus. This suggested an inadequate handling of cheese at the sale markets or during grating as indicated in the present research.

Although storage temperature could have influenced the results, all samples were maintained at the same temperature. Therefore, storage temperature is likely not responsible for the differences observed in the microbial populations between groups. At present, there is no ordinance that sets a maximum limit for Staphylococcus count allowed in parmesan cheese. However, the RDC n. 12 (BRAZIL, 2001) sets a limit for Staphylococcus that produce coagulase enzyme; $\boldsymbol{S}$. aureus is the main coagulase-producing species. According to this ordinance, the maximum count allowed for coagulase-positive Staphylococcus is $10^{3} \mathrm{CFU} \cdot \mathrm{g}^{-1}$.
In our studies, the coagulase-positive Staphylococcus count was $<10$ to $5.1 \times 10^{3} \mathrm{CFU} \cdot \mathrm{g}^{-1}$ in the IG samples and $<10$ to $3.6 \times 10^{6} \mathrm{CFU} \cdot \mathrm{g}^{-1}$ in the GTS samples. Samples in the latter group had higher count of Staphylococcus coagulase-positive bacteria; out of 60 samples, $88.3 \%$ had counts higher than the limits allowed by the legislation, whereas only $16.6 \%$ of the IG group had higher counts. When compared using the Dunn's test $(\mathrm{P}>0.05)$, no significant difference in microbial count was observed among the samples in the GTS group.

The highest count of Staphylococcus coagulase-positive bacteria observed in the IG samples was $5.1 \times 10^{3} \mathrm{CFU} \cdot \mathrm{g}^{-1}$. When compared using the Dunn's test $(\mathrm{P}<0.05)$, no significant differences were observed within the GTS group. Using the Dunn's test $(\mathrm{P}<0.05)$, the B and D (IG) and $E$ (GTS) brands were not statistically different compared with the IG and GTS groups. Overall, the

Table 2 - Arithmetic means and standard deviation of Staphylococcus spp., positive-coagulase Staphylococcus, and S. aureus reported in each brand of industrially grated (IG) and grated at the time of sale (GTS) parmesan cheese collected from markets at Ribeirão Preto, São Paulo.

\begin{tabular}{lccc}
\hline & & & \\
Brand & Staphylococcus spp. & Positive-coagulase Staphylococcus & S. aureus \\
\hline A (IG) & $4.7 \times 10^{3 \mathrm{a}} \pm 2.4 \times 10^{3}$ & $2.6 \times 10^{2 \mathrm{c}} \pm 4.3 \times 10^{2}$ & $2.6 \times 10^{2 \mathrm{a}} \pm 4.3 \times 10^{2}$ \\
B (IG) & $7.4 \times 10^{3 \mathrm{a}} \pm 5.1 \times 10^{3}$ & $9.6 \times 10^{2 \mathrm{bc}} \pm 1.4 \times 10^{3}$ & $9.6 \times 10^{2 \mathrm{a}} \pm 1.4 \times 10^{3}$ \\
C (IG) & $3.9 \times 10^{3 \mathrm{a}} \pm 2.6 \times 10^{3}$ & $<1 \times 10^{\mathrm{c}}$ & $<1 \times 10^{\mathrm{a}}$ \\
D (IG) & $5.2 \times 10^{3 \mathrm{a}} \pm 3.7 \times 10^{3}$ & $5.7 \times 10^{2 \mathrm{bc}} \pm 9.1 \times 10^{2}$ & $3.5 \times 10^{2 \mathrm{a}} \pm 4.9 \times 10^{2}$ \\
E (GTS) & $2.8 \times 10^{6 \mathrm{~b}} \pm 1.6 \times 10^{6}$ & $8.1 \times 10^{5 \mathrm{~b}} \pm 6.8 \times 10^{5}$ & $7.1 \times 10^{5 \mathrm{~b}} \pm 6.6 \times 10^{5}$ \\
F (GTS) & $3.7 \times 10^{6 \mathrm{~b}} \pm 1.9 \times 10^{6}$ & $1.0 \times 10^{6 \mathrm{a}} \pm 8.1 \times 10^{5}$ & $1.0 \times 10^{6 \mathrm{~b}} \pm 8.6 \times 10^{5}$ \\
G(GTS) & $2.9 \times 10^{6 \mathrm{~b}} \pm 2.2 \times 10^{6}$ & $1.1 \times 10^{6 \mathrm{a}} \pm 1.1 \times 10^{6}$ & $1.0 \times 10^{6 \mathrm{~b}} \pm 1.1 \times 10^{6}$ \\
H (GTS) & $3.0 \times 10^{6 \mathrm{~b}} \pm 2.3 \times 10^{6}$ & $1.3 \times 10^{6 \mathrm{a}} \pm 1.0 \times 10^{6}$ & $1.3 \times 10^{6 \mathrm{~b}} \pm 1.0 \times 10^{6}$ \\
\hline
\end{tabular}

Means followed by the same letters in the column do not differ according to the Dunn's test ( $5 \%$ significance level).

Ciência Rural, v.46, n.12, dez, 2016. 
GTS brands had higher bacterial counts than those in the IG samples.

The origin of coagulase-positive Staphylococcus contamination is usually related to poor raw material quality, lack of proper sanitation of equipment and utensils, and poor personal hygiene of food handlers (NOGUEIRA et al., 2013). Results on contaminant population reported in the IG and GTS groups in this study are similar to those in other reports (NOGUEIRA et al., 2013; ABREU et al., 2010a). Several pathogenic microorganisms (including coagulase-positive Staphylococcus) can survive in food residues or water in inadequately sanitized utensils, (DEVITA et al., 2007), reinforcing the fundamental role of the food handler's hygiene and the need for implementing good food handling practices.

The GTS group showed a clear lack of equipment and personal hygiene compared with that in the IG group, although cheese in both groups was produced under sanitary conditions. Among the coagulase-producing species, $\boldsymbol{S}$. aureus is one of the most frequently involved species in foodborne outbreaks. In the present study, $\boldsymbol{S}$. aureus was found at counts of $<10$ to $5.1 \times 10^{3} \mathrm{CFU} \cdot \mathrm{g}^{-1}$ in IG parmesan and $<10$ to $3.6 \times 10^{6} \mathrm{CFU} \cdot \mathrm{g}^{-1}$ in GTS parmesan.

Among the samples tested, $15.0 \%$ and $86.6 \%$ of the cheese samples contained more than $10^{3} \mathrm{CFU} \cdot \mathrm{g}^{-1}$ of bacteria in the IG and GTS groups, respectively. When the means were analyzed by Dunn's test $(\mathrm{P}<0.05)$, all IG group samples differed significantly from the GTS group samples. Consequently, based on our results, it is possible to affirm that the population of $\boldsymbol{S}$. aureus was significantly higher in the GTS parmesan than in the IG parmesan, thus posing a public health concern, mainly due to the risk of consuming of toxins produced during improper food storage and handling (SOUZA, 2006). Approximately $50 \%$ of the human population is a carrier of the bacterium (BERGDOLL \& BENNETT, 1989), which can lead food contaminations, such as during the grating process involved in the handling of parmesan cheese.

The amount of mold and yeast in the IG samples varied from $<10$ to $4.0 \times 10^{3} \mathrm{CFU} \cdot \mathrm{g}^{-1}$ and from $<10$ to $1.8 \times 10^{6} \mathrm{CFU} \cdot \mathrm{g}^{-1}$ in the GTS samples. Brand $F$ cheese (IG group) did not statistically differ from the samples of the GTS group. The mean values of other brands differed among each other (Dunn's test, $\mathrm{P}<0.05$ ). Therefore, in terms of mold and yeast counts, IG parmesans (with the exception of brand F) have better microbial quality than GTS parmesans.
In this study, $25 \%$ of the IG samples exhibited fungal counts higher than $10^{3} \mathrm{CFU} \cdot \mathrm{g}^{-1}$. Conversely, $90 \%$ of the GTS samples had counts higher than $10^{3} \mathrm{CFU} \cdot \mathrm{g}^{-1}$. The presence of a high fungal population in food can indicate deterioration, even when there no visible signs. It is crucial to note that some filamentous fungi species can produce mycotoxins, which are potential carcinogenic compounds (HYMERY et al. 2014) and can lead to serious health problems.

According to ABREU et al. (2010b), among all microorganisms, fungi most commonly benefit from low water activity situations. This explains the high count of yeast and mold obtained in this research. Moreover, producing food in poor sanitary conditions can enhance the multiplication of these microorganisms (MATTAR et al., 2011).

However, some other factors have an inhibitory effect on fungal multiplication. According to TROMBETE et al. (2012), 100.0\% of food samples analyzed in their study contained sorbic acid, which is a preservative. Manufacturers frequently use sorbic acid salts in cheese and other dairy products as they reduce fungal growth and increase the shelf life of the product (SALAVESSA, 2009). Despite the inhibitory effect of this preservative, the fungal count remained quite high in the samples analyzed in our study, mainly in the GTS group, which suggested contamination due to inadequate handling at sale time.

\section{CONCLUSION}

The parmesan cheese samples of GTS group showed higher counts of contaminants than those of the IG group, resulting in a higher probability of harboring pathogenic and deteriorating microorganisms. Thus, all 60 samples of the GTS group were in disagreement with the current legislation and scientific literature in terms of microbiological quality for consumed food, suggesting an improper manipulation of the cheese at the point-of-sale.

\section{ACKNOWLEDGEMENTS}

The study was supported with Coordenação de Aperfeiçoamento de Pessoal de Nível Superior (CAPES) grant.

\section{REFERENCES}

ABREU, E.S.A. et al. Effectiveness by methods of utensils hygiene on restaurants. Revista Simbio-Logias, v.3, p.132-143, 2010a. Available from: <http://www.ibb.unesp.br/Home/Departamentos/ Educacao/Simbio-Logias/eficacia_metodos_higienizacao_ utensilios.pdf>. Accessed: Aug. 09, 2016. 
ABREU, A.N.I. et al. Microbiological evaluation of grated cheese and cream cheese marketed in Minas Gerais. In: XIX CONGRESSO DE PÓS-GRADUAÇÃO DA UFLA, 2010, Lavras, MG. Anais... Lavras: UFLA - Pró-Reitoria de Pesquisa, 2010b. Available from: <http://www.sovergs.com.br/site/higienistas/ trabalhos/10114.pdf>. Accessed: Aug. 09, 2016.

AMERICAN PUBLIC HEALTH ASSOCIATION (APHA). Compendium of methods for the microbiological examination of foods. Washington, 2001. 975p.

ARGUDÍN, M.A et al. Genotypes, exotoxin gene content and antimicrobial resistance in Staphylococcus aureus recovered from food and food-handlers. Applied and Environmental Microbiology, v.78, p.2930-2935, 2012. Available from: <http:// dx.doi.org/10.1128/AEM.07487-11>. Accessed: Aug. 09, 2016. doi: 10.1128/AEM.07487-11.

BEAN, N.H. et al. Surveillance for foodborne disease outbreaks - United States, 1988-1992. Journal of Food Protection, v.60, p.1265-1286, 1997. Available from: <http://www.ncbi.nlm.nih. gov/pubmed/8890258?dopt>. Accessed: Aug. 09, 2016.

BERGDOLL, M.S.; BENNETT, R.W. Compendium of methods for the microbiological examination for foods. Washington: American Public Health Association, 1989. ch. 34, p. 428-457.

BRASIL, Ministério da Agricultura, Pecuária e Abastecimento. Portaria n. 357, de 04 de Setembro de 1997. Diário Oficial da União, Brasília. Seção 1, 1997.

BRAZIL. Ministério da Saúde: Resolução - RDC n.12, 2 de janeiro de 2001. Diário Oficial da União, Brasília, p.1-48, 2001.

DAMER, J.R.S. et al. Qualidade higiênico-sanitária de sorvetes tipo italiano e de massa (artesanal e industrializado) comercializados na região noroeste do Rio Grande do Sul, Brasil. Demetra, v.10, p.821-834, 2015. Available from: <http://dx.doi.org/10.12957/demetra.2015.16010>. Accessed: Aug. 09, 2016. doi: 10.12957/demetra.2015.16010.

DEVITA, M.D. et al. Assessing the potential of Streptococcus pyogenes and Staphylococcus aureus transfer to foods and customers via a survey of hands, hand contact surfaces and food contact surfaces at foodservice facilities. Journal of Food Service, v. 18, p.76-79, 2007. Available from: <http://dx.doi.org/10.1111/j.1745-4506.2007.00049. $\mathrm{x}>$. Accessed: Aug. 09, 2016. doi: 10.1111/j.1745-4506.2007.00049.x.

GAULIN, C. et al. Widespread listeriosis outbreak attributable to pasteurized cheese, which led to extensive cross-contamination affecting cheese retailers, Quebec, Canada, 2008. Journal of Food Protection, v.75, n.1, 71-78, 2012. Available from: <http://www. ncbi.nlm.nih.gov/pubmed/22221357>. Accessed: Aug. 09, 2016. doi: 10.4315/0362-028X.JFP-11-236.

HYMERY, N. et al. Filamentous fungi and mycotoxins in cheese: a review. Comprehensive Reviews in Food Science and Food Safety, v.13, n.4, p.437-456, 2014. Available from: <http://dx.doi. org/10.1111/1541-4337.12069>. Accessed: Aug. 09, 2016. doi: 10.1111/1541-4337.12069.

ICMSF (INTERNATIONAL COMMISSION ON MICROBIOLOGICAL STANDARDS FOR FOODS). Microrganismos de los alimentos: métodos de muestro. In: CANDERZANT, C.; SPLITTSTOESSER, D.F. Para análisis microbiológicos: princípios y aplicaciones especificas. Zaragoza: Acribia, 1981. Cap.8, p.91-103.
JASTER, H. et al. Quality evaluation of parmesan type cheese: a chemometric approach. Food Science and Technology, v.34, n.1, p.181-188, 2014. Available from: <http://dx.doi.org/10.1590/ S0101-20612014000100026>. Accessed: Aug. 09, 2016. doi: 10.1590/S0101-20612014000100026.

JAY, J.M. Microbiologia de alimentos. Porto Alegre: Artmed, 2005. 712p.

KANDARIYA, J. et al. Staphylococcus aureus and staphylococcal food-borne disease: an ongoing challenge in public health. BioMed Research International, v.2014, p.1-9, 2014. Available from: <http://10.1155/2014/827965>. Accessed: Aug. 09, 2016. doi: $10.1155 / 2014 / 827965$.

MACFADDIN, J.F. Biochemical tests for identification of medical bacteria. Baltimore: Williams and Wikkins, 1976. 312p. Available from: <http://dx.doi.org/10.1155/2014/827965>. Accessed: Aug. 09, 2016. doi: 10.1155/2014/827965.

MADIC, J. et al. Detection of Shiga toxin-producing Escherichia coli serotypes O26: H11, O103: H2, O111: H8, O145: H28, and O157: H7 in raw-milk cheeses by using multiplex real-time PCR. Applied and environmental microbiology, v.77, n.6, p.2035-2041, 2011. Available from: <http://dx.doi.org/10.1128/AEM.02089-10>. Accessed: Aug. 09, 2016. doi: 10.1128/AEM.02089-10.

MARINHEIRO, M.F. et al. Qualidade microbiológica de queijo mussarela em peça e fatiado. Semina: Ciências Agrárias, v.36, p.1329-1334, 2015. Available from: <http://dx.doi. org/10.5433/1679-0359.2015v36n3p1329>. Accessed: Aug. 09, 2016. doi: $10.5433 / 1679-0359.2015 \vee 36 n 3 p 1329$.

MATTAR, T.V. et al. Análise da qualidade microbiológica de queijo ralado. In: XXIV CONGRESSO DE INICIAÇÃO CIENTÍFICA DA UFLA, 2011, Lavras, MG. Anais... Lavras: UFLA - Pró-Reitoria de Pesquisa, 2011. Available from: <http://www.prp.ufla.br/ciuflasig/ generateResumoPDF.php?id=818>. Accessed: Aug. 09, 2016.

MELLO, E.Z.; ARMACHUK, M.A. Avaliação do queijo colonial durante a maturação: modificações físico-químicas e microbiológicas. 2013. 76f. Monografia (Conclusão de Curso de Graduação) - Universidade Tecnológica Federal do Paraná, Francisco Beltrão, PR. Available from: <http://repositorio.roca. utfpr.edu.br/jspui/handle/1/2087>. Accessed: Aug. 09, 2016.

MONTANHINI, M.T.M. et al. Effect of temperature on the lipolytic and proteolytic activity of Bacillus cereus isolated from dairy products. International Food Research Journal, v.20, n.3, p.1417-1420, 2013.

NOGUEIRA, A.M.S. et al. Análise da qualidade microbiológica de queijo ralado comercializado em São José do Rio Preto - SP. Revista Cientifica Unilago, v.1 p.129-136, 2013.

SALAVESSA, J.J.S.M. Salsicharia tradicional da zona do Pinhal: caracterização e melhoramento da tecnologia de fabrico dos Maranhos. 2009. 321f. Tese (Doutorado em Ciência e Tecnologia Animal) - Faculdade de Medicina Veterinária, Universidade Técnica de Lisboa. Available from: <http:/hdl. handle.net/10400.5/2843>. Accessed: Aug. 09, 2016.

SCALLAN, E. et al. Foodborne illness acquired in the United Statesmajor pathogens. Emerging Infectious Diseases, v.17, n.1, p.7-15, 2011.

SEIXAS, F.R.F. et al. Verificação da qualidade microbiológica de saladas adicionadas de maionese, comercializadas no município de 
São José do Rio Preto, SP. Higiene Alimentar. São Paulo, v.23, n.172/173, p.142-149, 2009.

SILVA, A.S. Avaliação higiênico-sanitária, através de análises microbiológicas, de alimentos produzidos e comercializados em uma grande rede de hipermercados em Salvador-BA. Revista do Instituto Adolfo Lutz, v.70, n.4, p. 651-651, 2011. Available from: <http:// periodicos.ses.sp.bvs.br/scielo.php?script=sci_arttext\&pid=S007398552011000400031\&lng=pt\&nrm=iso >. Accessed: Aug. 09, 2016

SOTO, F.R.M. et al. Experimental application of a sanitary inspection model in the retail food market. Food Science and Technology, v.29, n.2, p.371-374, 2009. Available from: <http:// dx.doi.org/10.1590/S0101-20612009000200021>. Accessed: Aug. 09, 2016. doi: 10.1590/S0101-20612009000200021.
SOUZA, L.H.L. The inadequate food handling: contamination factor. Higiene Alimentar, v.20, p.32-39, 2006.

THEODORSSON-NORHEIM, E. Kruskal-Wallis test: BASIC computer program to perform nonparametric one-way analysis of variance and multiple comparisons on ranks of several independent samples. Computer Methods and Programs in Biomedicine. v.23, p.57, 1986 .

TROMBETE, F.M. et al. Avaliação da qualidade química e microbiológica de queijo parmesão ralado comercializado no Rio de Janeiro. Revista do Instituto de Laticínios "Cândido Tostes", v.67, p.11-16, 2012. Available from: <http://dx.doi. org/10.5935//2238-6416.20120017>. Accessed: Aug. 09, 2016. doi: $10.5935 / / 2238-6416.20120017$ 